\title{
TWEE ROOFTOCHTEN MET TRAGISCHEN AFLOOP. \\ DOOR
}

\author{
C. K. KESLER.
}

Nadat in de $16 \mathrm{e}$ eeuw de vestiging van Hollanders, Engelschen en later ook Franschen in de West-Indiën begonnen was, werd in de 17e eeuw de Caraïbische Zee in niet mindere mate dan de Noordzee en de Middellandsche Zee het tooneel, waarop uitgevochten werd, wie van die drie de boventoon zou voeren en, heeft ook al de $18 \mathrm{e}$ eeuw de onbetwiste beheersching der zee door de Engelschen gebracht, in de 17e eeuw was de strijd daarom in vollen gang. Vooral de beide, door de Noordzee gescheiden concurrenten bestreden elkaar hardnekkig en de Franschen hielpen daarbij nu eens aan deze, dan weer aan gene zijde, maar speelden veel vaker de rol van zeer belangstellende toeschouwers, die niet ongaarne zagen, dat de beide voornaamste mededingers elkander vernielden. Dat gebeurde reeds in 1667 in het gevecht bij Nevis tusschen Abraham Crijnssen en de vloot van Lord Willoughby, waar de Franschen, toen onze bondgenooten, zich onder De la Barre buiten het vuur hielden, in 1672 in den slag bij Solebay, toen d'Estrées de Engelschen zeer onvoldoende bijstond, en bij andere gelegenheden. Kwam het er echter op aan, alleen de Hollanders te bevechten, dan streden ook in de Westindische wateren en te land de Franschen met weergalooze volharding en van weerszijden was blijkbaar het doel, elkander zooveel mogelijk schade toe te brengen en vooral, elkanders schepen en versterkingen te vernielen.

Cayenne en het eiland Tobago waren de plaatsen, waar in het bijzonder de Fransche en Hollandsche belangen el- 
kander kruisten en die nu eens aan deze, dan weer aan gene mogendheid behoorden. Op beide hadden wij ongetwijfeld de oudste rechten, zooals trouwens in vele opzichten de Fransche mededingers in de 17e eeuw slechts navolgden en uitbreidden, wat zij van het geminachte volk van kramers en visschers gezien en geleerd hadden. Immers, voor een goed deel had de Fransche marine haar oorsprong te danken aan Hollandsche bedrijvigheid, maar al te vaak veroorzaakt door winstbejag, of afgunst op in handel en nering fortuinlijker mededingers. De Moucheron, Lijntgens, Lemaire en anderen zijn daarvan bekende voorbeelden, wat de handelsvloot betreft, en, toen Lodewijk XIII en vooral Lodewijk XIV er ernst van begonnen te maken, om Frankrijk naast Engeland en de Republiek een rol ter zee te doen spelen, wendden zij hun blikken vooral naar de laatste, om na te volgen, wat daar tot stand was gebracht en niet het minst, om vandaar matrozen en ervaren gezagvoerders te verkrijgen. Vooral Colbert, wiens economisch stelsel het bezit van koloniën voor Frankrijk noodzakelijk maakte, was, sedert 1665 bijgestaan door zijn zoon De Seigneley, rusteloos bezig, Frankrijk tot het innemen van een waardige plaats in de rij der koloniale mogendheden in staat te stellen. Daartoe deed hij de voor den zeedienst geschikten in 1665, eerst als proef in drie provinciën en drie jaar later in het geheele land inschrijven, omschreef nauwkeurig hunne rechten en verplichtingen en bevorderde zooveel mogelijk het aanbouwen en krachtig bewapenen van nieuwe schepen.

Die belangstelling in marine- en koloniale zaken bracht vanzelf Frankrijk op verschillende punten van den aardbol in botsing met Nederlanders en Engelschen, in WestIndië vooral daar, waar handels- of koloniale belangen tot vestiging uitlokten. Dat had Cayenne reeds sedert het begin van onze vaart op de West gedaan door zijne ligging aan de N. O.-kust van Zuid-Amerika, niet zoo heel ver van de Amazone-rivier, waarheen wind en stroom de van de Canarische of Kaapverdische eilanden komende schepen vanzelf heendreven. Reeds sedert het laatst der 16e eeuw, tusschen 1595 en 1600 werden er verschillende toch- 
TWEE ROOFTOCHTEN MET TRAGISCHEN AFLOOP. 611

ten door Hollandsche schepen naar die streken gedaan. In 1596 b.v. vertrokken daarheen twee schepen, uitgezonden door De Moucheron in compagnieschap met den Middelburgschen burgemeester Adriaan Hendriksz. ten Haeff en reeds omstreeks dienzelfden tijd ontstond een plan tot kolonisatie van die streken, niet onwaarschijnlijk van Usselincx afkomstig.

Dat in Holland de belanghebbenden reeds vroeg met de Zuid-Amerikaansche kusten bekend waren, blijkt o.a. uit het in 1599 bij de Staten-Generaal ingediende verslag van A. Cabeljau, die als Commies-generaal met het schip de Zeeridder een groot deel van de Noordkust van ZuidAmerika bezocht. Volgens dit verslag, getiteld „Verclaringe van de onbekende ende onbeseylde voiage van America, beginnende van de riviere Amasonis tot het eylant van de Trinitat toe", bleven de zeelieden eenige maanden in de nabijheid van Cayani, of Cayenne, om handel te drijven met de Galibi's. en het blijkt, dat de reeders in de Republiek, vooral in Zeeland; trachtten van de opgedane ervaring te profiteeren en aanvankelijk telkens pogingen deden, om vasten voet te krijgen in het tegenwoordige Fransch Guyana. In 1627 gaat Claude Prévost, een Franschman in dienst van de Staten van Zeeland, naar de Amazone en vandaaı naar Cayenne, met opdracht daar eene kolonie te vestigen en in hetzelfde jaar vertrekken drie schepen onder opperbevel van Hendrik Jacobsz. Lucifer naar de Wiapoco of Oyapoc, de grensrivier van het tegenwoordige Fransch Guyana en Brazilië. Beide kolonisaties mislukken, doch men gaf het niet op en in 1634 doet David Pietersz. de Vries opnieuw een poging ,om zich in Cayenne te vestigen. Aanvankelijk gelukt de onderneming, die door den schipper, in strijd met de bepalingen van het octrooi der W. I. C. in compagnieschap met Jan Bicker van Amsterdam voor eigen rekening ondernomen was, vrijwel, doch in Nieuw-Nederland aangekomen, vernam de stichter, dat de door hem achtergelaten kolonisten met een buitgemaakt Spaansch slavenschip de vestiging reeds weder verlaten hadden.

Intusschen had zich ook belangstelling van anderen 


\section{TWEE ROOFTOCHTEN MET TRAGISCHEN AFLOOP.}

voor dat deel van Zuid-Amerika geopenbaard, vooral van de zijde van de in 1643 te Rouaan gevestigde handelscompagnie en van de in 1652 door Lodewijk XIII geoctrooieerde Compagnie du Cap Nord. Deze laatste zond eene expeditie uit, waarbij zich 800 mannelijke en vrouwelijke kolonisten bevonden, die de stad Cayenne stichtten, doch voortdurend strijd hadden te voeren met de Indianen, waarom een groot deel dezer Franschen in 1654 naar Suriname de wijk namen.

Twee jaar later beproeven de Hollanders het nog eens, zich in Cayenne te vestigen. Guérin Spränger sluit een contract met Balthasar Gerbier, bai on Douvily, om goud te zoeken en vestigt zich in het door de meeste Franschen verlaten gebied. Eenigen tijd daarna versterkt door Joodsche vluchtelingen uit Brazilië,scheen het, alsof deze vestiging met meer succes zou bekroond worden dan de vroegere. Den 12en September 1659 verleende de W. I. C. aan - David Cohen Nassy octrooi tot het stichten van eene patroons-kolonie en vier jaar lates, in 1663, werd door de Kamer van Amsterdam eene expeditie uitgezonden tot versterking der vestiging. Ook deze had echter reeds den langsten tijd bestaan, want in hetzelfde jaar 1663 werd in Frankıijk opgericht de Compagnie Equinoxiale, later bekend onder den naam van Compagnie des Indes Occidentales. Deze zond onder bevel van De Tracy en La Barre een vloot uit met opdracht Cayenne weer in bezit te nemen. Spränger zag zich genoodzaakt, zijne kolonie over te geven en kort daarop werden ook de Joden verdreven, die zich daarop, zooals bekend is, in Suriname en andere Hollandsche koloniën vestigden.

Omstreeks dien tijd begon ons koloniaal bezit in de West bedenkelijk in te krimpen en gingen de zaken van de W. I. C. alles behalve naar wensch. Brazilië, dat wij sedert 1630 bezet hadden, ging in 1661 voor goed verloren; Nieuw-Nederland drie jaar later eveneens, zoodat wij na het verlies van Cayenne nog slechts vasten voet hadden op Curaçao en enkele andere eilandjes en een paar punten op de Vaste Kust, n.l. Essequebo en Berbice. Het leek er dus zeer op, dat het doel der Engelschen en Franschen be- 
reikt zou worden, en dat de Hollandsche vlag binnen kort geheel uit Amerika zou verdwijnen. Doch zoover kwam het niet. De bekende tocht van Abraham Crijnssen, als antwoord op de rooftochten der Engelschen naar onze Afrikaansche bezittingen en Nieuw-Nederland verschafte ons voor goed vasten voet in Suriname en bracht ook Tobago, dat reeds zoovele malen van heer veranderd was, opnieuw in ons bezit.

Om dat eiland Tobago, door Hamelberg aangeduid als „een vergeten Nederlandsche kolonie”, was voor en na reeds heel wat gestreden. Achtereenvolgens was het voor korten tijd in handen van Spanjaarden, Engelschen, Zeeuwen, Franschen en anderen geweest en zoowel Karel I en Karel II van Engeland, als Lodewijk XIV beleenden er nu dezen, dan weer dien mede. Sedert 1654 was in de Republiek de aandacht der gebroeders Lampsins, de patroons van De Ruyter en Crijnssen, er op gevallen. Adriaan, de oudste, bewindhebber der Kamer van Zeeland in de O. I. C., hield zich meer met andere zaken bezig, doch de jongste, Cornelis, Raad en in de jaren 1650, '51 en '52 Burgemeester van Vlissingen, was het, die vooral belang stelde in de Westindische zaken. Franschgezind, had hij er geen bezwaar tegen, nadat hij reeds van de Staten van Zeeland Tobago verkregen had, zich als patroon der kolonie daar, te doen erkennen door Lodewijk XIV. Dat geschiedde in 1662; Cornelis Lampsins werd toen Baron van Tobago en eenigen tijd daarna Ridder van St.-Michel. Aanvankelijk scheen het, alsof de kolonie nu een goede toekomst te gemoet ging; een groot deel van het eiland werd in cultuur gebracht, met den bouw van een stadje werd begonnen en een fort en andere versterkingen werden aangelegd. Maar het uitbreken van den tweeden Engelschen oorlog bracht nieuwe aanvallen door de Engelschen, gevolgd door eene herovering door onze toenmalige bondgenooten, de Franschen, die weghaalden, wat de eerste plunderaars nog hadden overgelaten en verwoestten, wat zij niet konden meevoeren. Abraham Crijnssen, die op zijn bekenden tocht in 1667 via Suriname, Berbice en Essequebo daar aankwam, nam het eiland opnieuw in bezit, 


\section{TWEE ROOFTOCHTEN MET TRAGISCHEN AFLOOP.}

legde er een kleine versterking aan en, nadat het na zijn vertıek naar Martinique nog eenigen tijd door de Franschen bezet was geweest, werd het ons bij den vrede van Breda teruggegeven. In 1667 bezaten wij dus in WestIndië, Suriname, Berbice, Essequebo, Tobago en de eilanden, die thans nog Nederlandsch zijn.

Rust zou daar echter voorloopig nog niet heerschen. De oorlog van 1672, die de Republiek aan den rand van den ondergang bracht, zette ook West-Indië opnieuw in vuur en vlam. De strijd liep wederom vooral over Cayenne en Tobago, terwijl ook Curaçao een oogenblik ernstig bedreigd werd. De aanleiding tot den strijd in de West kwam van onze zijde. In 1672 was de vloot der Republiek na den slag bij Solebay en na de mislukking van de door de Engelschen voorgenomen landing in Noord-Holland in de havens teruggekeerd en de Staten-Generaal besloten, dien winter geen vloot in zee te houden, doch gaven aan de verschillende admiraliteiten machtiging om te doen, wat hun geschikt zou voorkomen, om de vijanden in andere gewesten afbreuk te doen. Er waren toen vijf admiraliteits-collegiën, dat van de Maas, gevestigd te Rotterdam dat van Amsterdam, van Zeeland, gevestigd te Middelburg, van het Noorderkwartier, te Hoorn of Enkhuizen en dat van Friesland, eerst te Dokkum en sedert 1645 te Harlingen gevestigd. De Kamers der W. I. C. kwamen daarmede overeen, behalve in het Noorden, waar geen Kamer in Friesland was gevestigd, doch wel die van Stad en Lande te Groningen. De Admiraliteit van Amsterdam was de tweede in rang, doch legde in die dagen de grootste bedrijvigheid aan den dag en was inderdaad de voornaamste, wat voor een goed deel wel veroor zaakt werd door de gebeurtenissen na den dood van Willem II. Toen, nog niet gebreideld door de krachtige wil van Willem III, waren het de regenten van Amsterdam, die in de Republiek de koers aangaven en, doordat velen hunner òf zelf bewindhebbers van een der Compagniëen waren, òf door familieleden, als zoodanig vertegenwoordigd werden, ook in Oost en West. En zij konden dat doen, steunende op den rijkdom hunner stad, waardoor deze in den len Engel- 
schen oorlog tweemaal zooveel schepen kon leveren, als waartoe zij verplicht was en in den 2en in drie jaren 60 oorlogschepen van le en $2 \mathrm{e}$ charter kon laten bouwen op eigen werf. Terwijl de andere Admiraliteiten den bouw harer schepen moesten toevertrouwen aan particulieren, kon die van Amsterdam dit in eigen beheer verrichten, daar zij de eenige was, die in het bezit was van een scheepstimmerwerf van voldoende capaciteit, van een welvoorzien arsenaal en van groote lijnbanen. Deze inrichtingen waren tot stand gekomen, vooral door de energie van den Amsterdamschen burgemeester Nicolaas Witsen, neef en medestander van den leidenden burgemeester Johannes Hudde. Secretaris van de Admiraliteit was toen Hiob de Wildt, die eerst als assistent van zijn vader en later zelfstandig die betrekking bekleedde. Hij bezat het volkomen vertrouwen van De Witt en later van Willem III, van den laatste zoozeer, dat hij een der weinigen was, die op de hoogte waren van diens plannen ten opzichte van Engeland in 1688 en die in 1691 als zijn zaakgelastigde en vertegenwoordiger hem verving bij de vergaderingen der Admiraliteits-colleges. Die opdracht versterkte niet weinig de afgunst, die bij de andere reeds sedert jaren bestond ten opzichte van den invloed, dien Amsterdam zich gaandeweg had weten te verwerven. Alleen van het Noorderkwartier ondervond De Wildt in zijne functie medewerking; de andere Admiraliteiten trachtten hem zooveel mogelijk te negeeren en legden zijne adviezen menigmaal eenvoudig ter zijde. Samenwerking was er dus toen en trouwens ook in vroegere jaren zeer weinig. Dat bleek ook in 1672.

De Admiraliteit van Zeeland besloot toen, krachtens de machtiging van de Staten-Generaal een smaldeel naar de West te zenden, om te trachten, evenals in 1667 gelukt was, daar voordeel te behalen. Aan Amsterdam werd voorgesteld, deel te nemen aan de uit te zenden expeditie door bijvoeging van eenige schepen, wat echter geweigerd werd. Zooals spoedig bleek, had Amsterdam zijne eigen plannen, die het alleen wilde uitvoeren, waarschijnlijk vooral, daar het in het bijzonder de Kamer van Amster- 
dam der W. I. C. geweest was, die schade geleden had door het verlies van Nieuw-Nederland. In weerwil van Amsterdams weigering tot deelname, gaf Zeeland zijne plannen niet op en rustte vier schepen uit, die onder opperbevel van Cornelis Evertsen, den Jongen, 15 December 1672 zee kozen. De opperbevelhebber ontving voor zijn vertrek een geheimen lastbrief, waarin hem opgedragen werd, Engelsche of Fransche bezittingen op de Westkust van Afrika aan te vallen, en, zoo hij daar geene voldoende voordeelen mocht behalen, hetzelfde in Amerika te doen. De wijze van uitrusting wijst er op, dat de bedoeling was, van den aanvang af ontwijfelbaar vast te stellen, dat, wat veroverd zou worden, aan Zeeland behoorde en op die wijze moeilijkheden, als zich voorgedaan hadden na de bezetting van Suriname, in de toekomst te voorkomen.

Evertsen begaf zich eerst naar de Kaapverdische eilanden, werd daar echter bedreigd door vier Engelsche oorlogschepen en stak daarom over naar Cayenne, dat hij evenmin kon vermeesteren. Vandaar via Suriname naar Martinique gezeild, zạg hij plotseling zes schepen onder Fransche vlag naderen, die echter, toen Evertsen zijn vlag vertoonde, die vervingen door de Prinsenvlag. Het bleek een smaldeel te zijn onder opperbevel van Jacob Binckes, uitgezonden door de Admiraliteit van Amsterdam. Binckes, wiens vader burgemeester van Stavoren was, was reeds eenige jaren in dienst van de Admiraliteit van Amsterdam, waarschijnlijk daartoe gekomen, doordat twee zijner broeders zich in Amsterdam gevestigd hadden; de eene was equipage-meester der Admiraliteit, de andere Bewindhebber der O. I. C. In 1666 had hij deelgenomen aan den tweedaagschen zeeslag en in het volgende jaar aan den tocht naar Chattam. Het was dus niet te verwonderen, dat, toen bij Amsterdam het voornemen opkwam, evenals Zeeland gedaan had, te trachten, in West-Indië voordeelen te behalen, Binckes als opperbevelhebber aangewezen werd.

Nadat beide commandanten kennis genomen hadden van elkanders bevelschriften en het bleek, dat deze vrijwel gelijkluidend waren, kwamen zij overeen, samen te 
werken, een aanval op Martinique te doen en den buit, die behaald mocht worden, op redelijke wijze te verdeelen. Deze aanval mislukte echter; meer succes hadden zij met St.-Eustatius en Nieuw-Nederland, die beide heroverd werden, terwijl zij onderweg nog verscheidene schepen buit maakten. Behouden in het vaderland terug gekeerd, werden de beide bevelhebbers zeer verschillend door hunne respectieve lastgevers ontvangen. De Admiraliteit van Amsterdam betuigde aan Binckes hare tevredenheid over de uitvoering van zijn opdracht en schonk hem en zijnen kapiteins een extra belooning. De Staten van Zeeland echter riepen Evertsen ter verantwoording, vooral wegens de omstandigheid, dat hij Cayenne niet veroverd en zich zonder hun last met Binckes vereenigd had. Hij liep zelfs groot gevaar, ontslagen te worden en alleen de diensten, door zijne familieleden voor en na aan Zeeland bewezen, en de hoop, dat hij binnenkort zijne misslagen zou herstellen, behoedden hem daarvoor. Die ontevredenheid zijner lastgevers zal wel hierdoor veroorzaakt zijn, dat Evertsens tocht niet het voordeel had opgeleverd dat men zich had voorgesteld. Cayenne toch, waarom het vooral te doen geweest was, was in Fransche handen gebleven en Nieuw-Nederland, dat trouwens bij den vrede van Westminster in het volgend jaar aan Engeland werd teruggegeven, interesseerde Zeeland minder, daar het hoofdzakelijk eene Amsterdamsche kolonie geweest was. Vrij duidelijk openbaarde zich dus hier weer de Zeeuwsche afgunst op het overwicht van Amsterdam. Ook dit verloor intusschen noch Cayenne, noch Tobago uit het oog. Op het laatste eiland viel de aandacht door eene toevallige omstandigheid. In 1674 wendde een Westindische planter, Hendrick Carloff, die door den oorlog zware verliezen geleden had, zich tot den Secretaris der Amsterdamsche Admiraliteit, De Wildt, met plannen tot verovering van enkele punten in de West, in het bijzonder Tobago. Hij vond bij dezen een gunstig oor en De Wildt wist ook Willem III en den Raadpensionaris Fagel ervoor te winnen. Toen er echter iets van de besprekingen uitlekte en Zeeland een en ander van de plannen te weten 


\section{TWEE ROOFTOCHTEN MET TRAGISCHEN AFLOOP.}

kwam, vonden zij daar tegenstand en in een brief van den Zeeuwschen Raadpensionaris Pieter de Huybert aan Fagel, verzette de eerstgenoemde zich namens de Staten van zijn gewest tegen de verovering van Tobago, dat volgens hen nog steeds aan Zeeland toebehoorde. Amsterdam echter, dat zeer gesteld was op eene vergoeding voor het verloren Nieuw-Nederland, was niet van zins de eenmaal opgevatte plannen op te geven, waarom in het diepste geheim met de voorbereiding voortgang gemaakt werd. Die geheimhouding was dringend noodig, want weinig geschiedde er in de Republiek, dat niet door baatzuchtigen, die voordeel zagen in de gunst van den Franschen monarch, ten spoedigste aan dezen overgebriefd werd. Dat was reeds bij verschillende gelegenheden gebleken, o.a in 1674, toen bij den aanval van De Ruyter op Martinique bleek, dat de Franschen daar tot in bijzonderheden op de hoogte waren van het aantal en de sterkte zijner schepen, zoodat zij de noodige maatregelen hadden kunnen nemen om zich krachtig te verdedigen.

Bij de nu beraamde onderneming trachtte men zooiets te voorkomen; daarom werden er slechts een paar vertrouwde leden der Admiraliteit, waaronder natuurlijk De Wildt met de toebereidselen belast en werd er niets van in de notulen aangeteekend. Deze voorzorgen troffen doel, want ditmaal was het eskader reeds in West-Indië aangekomen en had daar reeds verschillende voordeelen behaald, voor men er in Frankrijk iets van gewaar werd. Wat daar verricht werd, was het volgende.

Binckes had onder zijne bevelen gekregen een eskader van vier schepen, drie adviesjachten en een fluit, voorzien van eene flinke bemanning en ruime voorraden en bovendien van 680 man landingstroepen. Als CommissarisGeneraal en tweede persoon in den krijgsraad was door den Prins benoemd Hendrick Carloff, die bestemd was, Gouverneur van Tobago te worden, zoodra dit veroverd zou zijn. $\mathrm{Na}$ in Maart 1676 van Tessel vertrokken te zijn, kwam het eskader 4 Mei voor Cayenne, dat door den Ridder De Lézy bestuurd werd. Binckes liet het fort opeischen en, toen de overgave geweigerd werd, deed hij den 
volgenden dag tot den aanval overgaan. Na een kort gevecht, waarbij aan Nederlandsche zijde 12 man vielen en 72 gewond werden, gaven de Franschen zich over en het veelbestreden Cayenne bevond zich dus weer in onze handen. Na een paar weken besteed te hebben aan de regeling der zaken en na Guérin Spränger als Gouverneur hersteld te hebben, wien hij een adviesjacht en ruim 200 man achterliet, vertrok Binckes in de richting van Tobago, doch, daar de wind niet gunstig was, begaf hij zich eerst naar Marie Galante, brandschatte dit en wilde hetzelfde doen met Guadeloupe. Hier ontmoette hij echter een paar Fransche oorlogschepen, die onder bevel van den Markies De Grancey troepen overbrachtten van Martinique, waaruit dus bleek, dat de Franschen thans op de hoogte waren van de bewegingen van het Nederlandsche eskader. $\mathrm{Na}$ een kort gevecht, waarna de Franschen wisten te ontsnappen, begaf Binckes zich naar St.-Martin, dat, hoewel oorspronkelijk in gemeenschappelijk bezit van Franschen en Hollanders geweest, bij het begin van den oorlog geheel door de Franschen bezet was. Ook dit eiland werd gedeeltelijk uitgeplunderd en hierna begaf een deel van het smaldeel zich naar Tobago, terwijl Binckes zelf met de rest naar Portorico en vandaar naar Haiti zeilde, waar hij nog eenige Fransche koopvaarders vermeesterde, die hij met de overige gemaakte buit vandaar naar de Republiek opzond. Daarop begaf hij zich eveneens naar Tobago, om de rest van zijn last ten uitvoer te brengen.

Daar aangekomen, vond hij niet alles naar wensch. Wel was het deel van zijn smaldeel, dat hij voor uit gezonden had, en waarop zich de a.s. Gouverneur Carloff bevond, aangekomen, doch de bevelhebber, de kapitein, die in rang op Binckes volgde, had zich met zijn schip eigenmachtig naar Holland begeven en de kolonisten aan hun lot overgelaten. Hiervoor werd hij het volgende jaar door de Staten-Generaal in staat van beschuldiging gesteld en na onderzoek zijner zaak schuldig bevonden en onthoofd. Daarbij kwam op Tobago nog, dat er gebrek aan levensmiddelen heerschte en dat het gerucht daar verspreid was, dat Cayenne weder in handen van den vijand gevallen 
was, waarop Binckes het noodig oordeelde, zoo spoedig mogelijk maatregelen van verdediging te nemen, vooral, ook, daar hij vernam, dat, naar men meende, een sterk Fransch eskader in aantocht was. Het bleek al spoedig, dat het bericht omtrent Cayenne juist was en dat zich inderdaad een sterk smaldeel van den vijand in de Caraibische zee vertoond had.

Dit stond onder bevel van den vice-admiraal Graaf Jean d'Estrées, een ouden kennis van onze zeelieden. Een aangenaam mensch in den omgang schijnt deze niet geweest te zijn; zijne onderbevelhebbers althans beklaagden zich nogal eens over zijn onverdraaglijken trots en bovendien gaf zijne bekwaamheid als bevelhebber ter zee vaak tot ernstige bedenkingen aanleiding, waarbij nog kwam, dat hij voor raadgevingen niet zeer toesankelijk was en liefst zijn eigen inzichten volgde. $\mathrm{Al}$ was die ook onaangenaam voor zijne ondergeschikten, te verklaren was zijn trots wel, evenals het niet te verwonderen was, dat de bevelen van den aanvoerder nogal eens met de eischen van goede zeemanschap in strijd waren. D'Estrées toch was een afstammeling van een geslacht, dat, hoewel niet tot de oudste behoorende, toch langen tijd in nauwe betrekking tot de Bourbons gestaan had en, waarvan verschillende leden Frankıijk in voorname waardigheden gediend hadden, of nog dienden. De grootste glorie, al is het er ook eene van eenigszins bedenkelijken aard, ontleende het geslacht aan de grootmoeder van den Vice-admiraal, de schoone Gabrielle, die wellicht koningin van Frankrijk geworden zou zijn, als haar plotselinge dood in 1599 dat niet verhinderd had, want Hendrik IV, wien zij reeds drie kinderen geschonken had, was voornemens, haar te huwen en daartoe zijn huwelijk met Margareta van Valois te doen ontbinden. Werkte deze verhouding reeds ertoe mede, het huis D'Estrées in nadere aanraking met de Bourbons te brengen, met wie het trouwens reeds in de $15 \mathrm{e}$ eeuw door aanhuwelijking verwant was geworden, vèrschillende krachtige figuren eruit waren als vanzelf aangewezen tot het bekleeden van gewichtige bedieningen in het leger, de diplomatie of de kerk. Zoo was de oudste 
TWEE ROOFTOCHTEN MET TRAGISCHEN AFLOOP.

broeder van Graaf Jean, François-Annibal, hertog d'Estrées, markies de Coeuvres, gezant van Frankrijk bij den Heiligen Stoel en werd in zijne functies ter zijde gestaan door zijn jongeren broeder César, bisschop van Laon en sedert 1671 kardinaal en zaakgelastigde van Frankrijk te Rome.

Evenals velen zijner voorvaderen had Jean d'Estrées eerst in het Fransche leger gediend, had deelgenomen aan de oorlogen der Fronde, was bij het beleg van Grevelingen in 1644 ernstig aan den linkerarm gekwetst en was in 1667 kolonel in het leger, dat onder Turenne Vlaanderen binnentrok. Verdere promotie bij het leger was echter voorloopig niet voor hem te verwachten, want de Markies de Louvois, de veelvermogende minister van oorlog, was hem vijandig, welk lot hij trouwens met velen, zooals b.v. Turenne en zelfs met Madame de Maintenon deelde. Daarom trachtte hij zijne verdere carrière bij de marine te maken, wat hem bijzonder goed gelukte, al waren zijne zeevaartkundige bekwaamheden, die hij in een paar jaren in Engeland trachtte op te doen, uit den aard deı zaak uiterst gering. $\mathrm{Na}$ in 1669 een tocht naar Amerika gedaan te hebben, werd hij in het volgende jaar naar West-Afrika gezonden als Vice-admiraal met Duquesne als onderbevelhebber en kommandeerde in 1673 het witte eskader van de Engelsch-Fransche vloot bij Kijkduin, waaraan hij slechts kort deelnam en zich, niet door gebrek aan moed, maar volgens geheime bevelen van zijn souverein, zooveel mogelijk buiten het vuur hield. In 1676 was hij buiten actieven dienst en deed, toen in Frankrijk bericht gekomen was van het uitzeilen van het Nederlandsche smaldeel naar de West en van het door Binckes daar verrichte, daar de Fransche oorlogsvloot in de Middellandsche zee werd bezig gehouden, aan Lodewijk XIV het voorstel, gedeeltelijk voor eigen rekening een eskader uit te rusten, om daarmee, hetzij bij de Kaapverdische eilanden, hetzij in de West, de Hollanders afbreuk te doen. Dergelijke expedities, die gedeeltelijk voor particuliere rekening, gedeeltelijk op kosten van het Rijk gedaan werden, waren toen ter tijd in Frankrijk volstrekt niet ongewoon. D'Es- 
trées' voorslag werd aangenomen en te zijner beschikking werden gesteld 4 schepen van 50 stukken geschut en 4 fregatten van 30 kanonnen. Voor de bewapening en de bemanning met 700 soldaten had D'Estrées te zorgen, terwijl de officieren voor de expedities zouden verschaft en betaald worden door de regeering. De opbrengst der eventueel prijs gemaakte schepen en verdere voordeelen zouden gelijkelijk door beide participanten gedeeld worden. Gaf deze laatste bepaling reeds eenigszins het karakter van een rooftocht aan de op touw gezette expeditie, nog sterker werd dit, doordat gerekend werd op de medewerking van de beruchte boekaniers en flibustiers in de Westindische wateren, terwijl het ook eigenaardig is, op te merken, dat de Fransche marine toen nog zoo weinig militair was, dat het voor de officieren niet verplicht was, uniform te dragen. Wel waren b.v. kapiteins gerechtigd tot het dragen van een wambuis met gouden of zilveren passement, maar verplichting daartoe bestond niet; zelfs droegen zij dit bij voorkeur niet, er prijs op stellende, door hunne persoonlijkheid en niet door hun uniform gehoorzaamheid van hunne ondergeschikten af te dwingen. Het waren trouwens hooge heeren, die onder de bevelen van D'Estrées gesteld werden; onder zijne officieren wemelde het van graven, ridders en heeren, zoowel onder zeeofficieren, als onder degenen, die het landings-corps kommandeerden. Bij de laatsten bevond zich ook de vroegere Gouverneur van Cayenne, de Riddeı De Lézy, die, bij de overgave krijgsgevangen gemaakt, door Binckes naar Holland was op gezonden, vandaar had weten te ontvluchten en $\mathrm{nu}$, als vrijwilliger op het smaldeel van D'Estrées meeging.

Nadat het Fransche eskader den 6en October 1676 uit Brest in zee gestoken was, kwam het na eenig oponthoud, veroorzaakt door het escorteeren van koopvaarders en door windstilte, via de Canarische en Kaapverdische eilanden op den 17en December voor Cayenne aan. Twee dagen later liet D'Estrées het fort door De Lézy opeischen, met de bedoeling, zooals hij in zijn rapport schrijft, gelegenheid te hebben, eenigszins de versterkingen te verkennen, daar hij niet verwachtte, dat de Hollanders zich 
TWEE ROOFTOCHTEN MET TRAGISCHEN AFLOOP. 623

op de eerste sommatie zouden overgeven. De opeisching werd dan ook met eene weigering beantwoord, waarom weer twee dagen later tot den aanval werd overgegaan, die gedeeltelijk geleid werd door D'Estrées in persoon. De bevelhebber van een andere afdeeling, de Heer de la Grand Fontaine, die een gebrek aan den voet had en daardoor niet loopen kon, liet zich in een draagstoel naar de plaats van het gevecht brengen en, hoewel één zijner dragers doodgeschoten werd, ging hij moedig voort den aanval van zijne afdeeling te leiden. De Hollanders werden min of meer overvallen. Daar de aanval bij nacht geschiedde, - den nacht na de opeisching was het volle maan geweest, waarom de aanval uitgesteld was, - en den vorigen avond, als naar gewoonte de taptoe op de schepen en in het kamp geslagen was, waren de Gouverneur en de bezetting niet voldoende op hun hoede; misschien ook hoopten zij, er af te zullen komen met eene eenvoudige plundering. Hoe het zij, na een gevecht, waarin van de zijde der Hollanders één officier en 32 soldaten vielen en 2 officieren en 35 manschappen gewond werden, waartegenover de Franschen een verlies leden van 2 officieren en 38 soldaten en matrozen aan gesneuvelden en 10 officieren en 95 manschappen aan gewonden, werd het fort veroverd en de Gouverneur Spränger met 230 à 235 kolonisten en soldaten gevangen genomen. Onder de gevangenen bevonden zich 4 Franschen, die bij de Hollanders in dienst waren en waarvan D'Estrées er een, als voorbeeld, liet ter dood brengen. De vroegere Gouverneur De Lézy werd in zijne functie hersteld en, nadat D'Estrées een en ander vernomen had van de beschikkingen, die Binckes intusschen op Tobago had laten nemen, begaf hij zich spoedig naar Martinique en Guadeloupe, versterkte zijn troepenmacht met enkele compagniën der bezetting daar en ging daarna onder zeil naar Tobago, waar hij hoopte aan te komen vóór Binckes, wat hem echter niet gelukte, want deze was reeds 14 dagen met zijn smaldeel op de reede voor anker, toen de Franschen 20 Februari 1677 aankwamen.

Van hunne bewegingen was Binckes vrij nauwkeurig op de hoogte, want onmiddellijk na zijn aankomst had hij 
een zijner onderbevelhebbers, den bekenden Jan Erasmus Reyning, uitgezonden, om aangaande het Fransche eskader berichten in te winnen. Deze had bij St.-Kitts een Fransche bark genomen, vanwaar, voor zij zich overgaf, twee pakketten over boord werden geworpen, die echter door Reynings manschappen werden opgevischt. Uit papieren, die zich daarin bevonden, bleek, dat de Fransche vloot binnen kort in West-Indië verwacht werd. Reyning deed daarna eenigen zijner manschappen op het veroverde schip overgaan en zond dit naar Tobago, terwijl hijzelf eerst naar St.-Eustatius en vandaar naar Barbados voer. Hier vernam hij, dat de verwachte Fransche vloot inderdaad was aangekomen, doch dat men niet wist, waarheen zij zich had begeven. Nadat hij het aldus gehoorde na zijn terugkomst aan Binckes gerapporteerd had, gelastte deze hem, met zijn schip aan den ingang van de baai te gaan liggen om de bewegingen der Franschen, die men reeds had zien voorbij varen, waar te nemen.

Het vijandelijke eskader dat intusschen genaderd was, bestond uit 10 oorlogschepen met bijna 500 stukken geschut en een kleine 5000 manschappen. Binckes' macht was niet meer, dan ruim $1 / 5$ daarvan, terwijl hij over ruim 350 stukken geschut beschikte. Allereerst zetten de Franschen een landingscorps van ongeveer 1000 man aan wal onder bevel van twee hoofdofficieren en op 22 Februari deed D'Estrées het fort opeischen, waarvan de overgave natuurlijk geweigerd werd. Den 3en Maart, Aschwoensdag, had een algemeene aanval plaats, zoowel van de land-, als van de zeezijde. Het geheele eskader zeilde daartoe naar binnen, na eerst het schip van Reyning verdreven te hebben door een aanval met een groot aantal gewapende sloepen. (14 volgens het rapport van D'Estrées). De aanval te land mislukte, doordat Binckes zijne voorzorgen goed genomen had en, doordat één der commandeerende Fransche officieren sneuvelde en de andere zwaar gewond werd. Het binnenzeilen van de baai geschiedde niet zonder bezwaren, want reeds voor den ingang was een der grootste schepen op een rots geloopen. In de baai ontwikkelde zich daarna een allerhevigst ge- 
vecht, in den loop waarvan een aantal schepen van beide zijden in brand geraakten, of in de lucht sprongen. Het admiraalschip van D'Estrées raakte ook in brand en de sloep, waarin hij zich trachtte te redden, werd lek geschoten, zoodat hij slechts met groote moeite aan wal kon komen, waarna hij met een veroverde Hollandsche sloep op een ander schip overging.

De Franschen leden zooveel schade en verliezen, dat zij het beter oordeelden, den aanval maar op te geven en af te trekken. Dit laatste ging niet gemakkelijk, want, was het binnenkomen der baai reeds met bezwaren gegaan, eruit konden de schepen slechts komen, door het uitbrengen van ankers vooruit, waarvan de kabels vervolgens opgewonden werden. Twee der grootste Fransche schepen moesten achtergelaten worden en drie andere waren in vlammen opgegaan, terwijl D'Estrées een paar duizend man, waaronder verscheidene bevelhebbers verloor. Van Hollandsche zijde waren de verliezen eveneens aanzienlijk ; vijf schepen verbrandden en aan dooden en gewonden verloren wij ongeveer 350 man. Tobago was echter voorloopig behouden en D'Estrées begaf zich met de overgebleven schepen naar Grenada, waar hij de gewonden ter verpleging achterliet en vandaar naar Frankrijk, om persoonlijk verslag van zijn mislukten tocht te doen. Hoewel men zich aan het hof te Versailles hield, alsof deze een groot succes geweest was en, hoewel er zelfs een medaille geslagen werd ter herinnering aan de „overwinning” bij Tobago, werd toch alles in het werk gesteld, om zoo spoedig mogelijk den aanval te herhalen.

In Holland verwachtte men natuurlijk ook, dat de Franschen niet in hun échec zouden berusten en de Admiraliteit van Amsterdam had gaarne versterking naar Tobago gezonden, maar zij bevond zich op dat tijdstip in groote geldverlegenheid. De hulp toch, in 1676 aan Spanje verleend, waartoe de Ruyter naar de Middellandsche Zee gezonden was, had voor Amsterdam eene uitgave geëischt van $f 450.000$, waarbij bovendien de overige provinciën, die echter in den regel en ook nu, niet zeer grif in hare betalingen voor de vloot waren, $f 300.000$ voor hare reke- 
ning zouden nemen. De rest van de kosten zou door Spanje gedragen worden. Daar Amsterdam op dat oogenblik dus eene hulp-expeditie niet kon bekostigen, wendde het zich tot de Staten-Generaal, die de andere provinciën aanmaanden, hunne achterstallige bijdragen te voldoen en ook het verzoek tot Spanje richtten om betaling van wat het nog schuldig was. Hiermede ging geruime tijd verloren en intusschen had Frankrijk niet stil gezeten, zoodat D'Estrées in het laatst van het jaar wederom met een eskader van Brest kon vertrekken en 30 November voor Barbados aankwam.

Vanhier begaf hij zich ten spoedigste opnieuw naar Tobago, vreezende, dat, indien hij te lang wachtte, Binckes maatregelen zou nemen, om eene landing te beletten. Den 6en December was het Fransche eskader van 12 schepen voor het eiland en onmiddellijk werden troepen aan land gebracht, wat de beide volgende dagen werd voortgezet, zoodat op den 8sten 950 man, behalve de officieren, met de noodige kanonnen gereed waren, het fort aan te vallen. $\mathrm{Na}$ enkele voorloopige gevechten begon op den 12en de beschieting daarvan en reeds bij het derde schot trof een bom het kruitmagazijn, dat in de lucht vloog, bij welks ontploffing Binckes met 16 zijner officieren benevens meer dan 250 manschappen omkwamen, waardoor dus op hoogst tragische wijze een einde kwam aan het leven van den man, die vele jaren met eere in de Nederlandsche zeemacht gediend had. D'Estrées, die juist aan tafel zat, deed na de ontploffing onmiddellijk tot den stormaanval overgaan en binnen een uur was, wat er van de Hollandsche bezetting over was, genoodzaakt, zich over te geven. Intusschen had de Admiraliteit van Amsterdam één oorlogschip en een paar kleine schepen naar Tobago gezonden, doch niet voor er een paar maanden verloopen waren, en hadden de Staten-Generaal besloten, Binckes en zijne mannen te doen aflossen door Tomas Tobyas, een Ier van geboorte, die sedert jaren voor Amsterdam voer. De hulp en de aflossing kwamen, helaas te laat; Tobago was voor goed voor ons verloren en, toen de door Amsterdam vooruitgezonden hulp-expeditie aankwam, was er 
TWEE ROOFTOCHTEN MET TRAGISCHEN AFLOOP. 627

niets meer te doen, dan de Hollanders, die, door in de bosschen te vluchten, aan krijgsgevangenschap waren ontkomen, van het, door de Franschen verwoeste en reeds weder verlaten eiland mede te voeren. D'Estrées had, reeds overeenkomstig de voorwaarden, waarop het gedeeltelijk verwoeste fort was overgegeven, 60 zwaar gewonde, of zieke krijgsgevangenen naar Curaçao doen overbrengen, was zelf naar Marinique teruggekeerd met het voornemen, na daar eenigen tijd rust genomen te hebben, zijn verwoestingstocht, die aanvankelijk ditmaal met zulk een succes was bekroond, voort te zetten. Het tweede gedeelte van zijn tocht zou echter een haast even tragisch einde hebben, als de expeditie van Binckes gehad had, met dit verschil echter, dat, terwijl deze zijne maatregelen uitstekend en met kennis van zaken genomen had, en slechts door een noodlottig toeval den dood vond, D'Estrées het onheil, dat kort na zijn vertrek van Martinique zijne vloot overkwam, zelf veroorzaakte door zijne inbeelding en zijn onwil, om goeden raad aan te nemen.

Den 7en Mei 1678 vertrokken, zeilde het eskader, bestaande uit 15 oorlogschepen en drie branders, vergezeld door eenige flibustiers, nadat de bevelhebber onderweg zijn voornemen had te kennen gegeven, eerst Curaçao aan te tasten in $Z$. Z. W. richting, denkende ongeveer op Orchilla aan te houden. In den loop van den oorlog was reeds een aanval op Curaçao gedaan door den Gouverneur van Martinique, De Bas, welke aanslag echter door de goede maatregelen van den Gouverneur Jan Doncker mislukt was. D'Estrées hoopte nu beter te slagen, al had hij ook zeer onvolledige inlichtingen omtrent de gesteldheid van het eiland ver kregen en al was hij volkomen onbekend met den te volgen weg. Herhaaldelijk had de kapitein van zijn admiraalschip, De Méricourt, bezwaar gemaakt tegen een dergelijken avontuurlijken tocht, doch D'Estrées had de gewoonte, wie met hem van meening verschilde, op zoodanige wijze af te snauwen, dat men zich ten slotte tegen beter weten in, maar bij zijne bevelen neerlegde. Het bleek intusschen maar al te spoedig, dat de voorzichtige kapitein gelijk gehad had met zijne bezwaren tegen het 
varen op een onbekende zee zonder voldoende voorzorgen en zonder met het vaarwater bekende loodsen. In den avond van den 9en Mei toch liep het grootste deel van het eskader op het Aves-rif, ten O. van Bonaire; blijkbaar was men dus door onbekendheid met den stroom ver naar het Westen afgedreven. Slechts 5 oorlogsschepen en eenige kleinere vaartuigen bleven van het geheele eskader over en ruim 500 man kwamen bij die ramp om het leven.

$\mathrm{Na}$ dezen tragischen afloop van zijn tocht gaf D'Estrées verdere aanslagen tegen Hollandsche of Spaansche koloniën in de West op en begaf zich met het treurig overschot van zijne vloot eerst naar St.-Domingo en keerde vandaar naar Martinique terug. Hoewel aldus onder zijne bevelen de Fransche zeemacht in de Westindische wateren tweemaal een belangrijk verlies aan schepen en menschenlevens geleden had, viel, merkwaardig genoeg, D'Estrées niet bij zijn koning in ongenade. Ter eere van de verovering van Tobago deed deze opnieuw gedenkpenningen slaan en de Vice-Admiraal werd in 1681 bevorderd tot Maarschalk van Frankrijk, ontving eenigen tijd later de ridderorde van den Heiligen Geest en stierf in 1707 als Gouverneur van Bretagne.

Voor de leden van de Amsterdamsche Admiraliteit, in zonderheid voor den Secretaris Hiob de Wildt, had het treurig einde van de Tobago-zaak intusschen nog een onaangenamen nasleep. Onder den indruk van het verlies, geleden door het gedeeltelijk verbranden van de vloot en van de latere overgave van het eiland, dienden de afgevaardigden van Amsterdam in de Staten van Holland eene klacht in, vooral tegen De Wildt gericht, waarbij deze en enkele leden der Admiraliteit beschuldigd werden, eigenmachtig en op onwettige wijze beschikt te hebben over de gelden en voorraden der Admiraliteit voor de onderneming op Tobago; aan de Staten verzochten zij een onderzoek hiernaar te gelasten en na rekening en verantwoording, indien daartoe termen gevonden werden, den Secretaris en eenige leden te veroordeelen tot terugbetaling der gebruikte gelden. De schriftelijke verantwoording van De Wildt was echter zoo afdoende, dat de Commissie, die 
TWEE ROOFTOCHTEN MET TRAGISCHEN AFLOOP. 629

voor het onderzoek der zaak benoemd was, adviseerde, hem en de andere leden vrij te spreken van wat hun was ten laste gelegd. Aldus werd dan ook besloten, hoewel onder tegenstand van Amsterdam, maar zeer waarschijnlijk onder invloed van Willem III en Fagel, die de onderneming zeer hadden bevorderd.

Geraadpleegde werken:

Mr. J. C. de Jonge, Geschiedenis van het Nederlandsche Zeewezen,1837.

E. Sue, Histoire de la Marine française. 1845.

P. M. Netscher, Geschiedenis van de koloniën Essequebo, Demerary en Berbice. 1888.

J. H. J. Hamelberg, De Nederlanders op de Westindische eilanden. 1901.

Jaarl. Verslagen v. h. Gesch., Taal.-, Land.- en Volk. Genootschap te Willemstad.

April, 1921. 